\title{
PHARMACOVIGILANCE OF AYURVEDIC MEDICINES IN INDIA: AN OVERVIEW
}

\author{
Dr. Shyam Babu Singh \\ Department of Ayurveda \\ Regional Ayurveda Research Institute For Drug Development \\ Gwalior, Madhya Pradesh, India
}

\begin{abstract}
Ayurveda is an ancient Indian system of medicine, which is being used for prevention and treatment of diseases since thousands of years. Over the time, the quality of herbs and Ayurvedic medicine has been changed due to different factors. At the same time with the increasing demand of Ayurveda in the world, it has become very necessary to ensure the effective and safe use of these medicines. For this, the Ministry of Ayush has started a pharmacovigilance program of AYUSH medicines. This paper intends to present a bird's eye view over the pharamcovigilance practice of Ayurvedic medicines in India.
\end{abstract}

Key words: Ayurveda, Ministry of Ayush, Pharmacovigilance

\section{INTRODUCTION}

Ayurveda is a science of life which is being practiced since thousands years back in India and now a day's getting more popularity in the western world. With its increasing acceptance it is being recognized at global level as a complete health care solution. In the past years some efforts have been made regarding the safety of Ayurvedic Drugs and implementation/uses of these drugs with minimum risk and high efficacy. Previously Ayurveda and other traditional therapies were included under ministry of family and health, but after the establishment of a separate Ministry named as 'AYUSH' Ministry, expectations from traditional medicine suddenly increased. In compliance to overcome those expectations Ministry of AYUSH, firmly took steps towards making sincere efforts in the assessment and monitoring of Ayurvedic drugs safety, enforcing risk control measures to ensure safe drug use. The development of National Pharamacovigilance programme has led to an increase in safety alert reports on Ayurvedic medicines to some extent. This paper presents a bird's eye view over the practice of drug practice surveillance in India and provides a perspective on the future developments of pharamacovigilance, taking into accounts the specific characteristics of Ayurvedic drugs.

\author{
Dr. Poornima Mansoria \\ Ayush Department Madhya Pradesh \\ Gwalior, Madhya Pradesh, India
}

\section{DISCUSSION}

Generally it is believed that Ayurvedic drugs are safe as they are being used since thousands of years, but frequently questions have been raised over the safety of Ayurvedic drugs. Besides the well known potential of the drug, Adverse Drug Reactions (ADR) risks are supposed to be appeared during the drug development procedure and during its clinical use practice. The probable factors related to the safety and efficacy are discussed as below;

Risk factors from the drug

The most important risk factor, which affects the safety of Ayurvedic Drugs, is the quality of the drug. The safety factors related to drug quality include the following aspects.

\section{A. Raw herbs}

India is a country with huge biodiversity, this features creates complexity in the species of the plants used their origins and their names. In addition to this, there are already so many conflicts with the similarity of names of different herbs mentioned in Ayurveda classics. Sometimes synonyms of the drugs name also create considerable confusion. As mentioned earlier the bio diversity of India produces a huge variation in the pharmacological property or functional component difference even in the same herb of different origin. Ayurveda has categorized the place of origin (land) into Sadharan, Anup and Jangal Desha. Flora and fauna of theses Desha (region) are entirely different from each other. Geographical and environmental conditions of the designated origin place affects the quality the herbs. Some herbs having high quality chemical profiles are more potent as they belong to the designated origin place and that is also reflected by its therapeutic efficacy and toxicity for instance Withania somnifera (Ashwagandha) of Nagaur (Rajasthan) contains highest withferineA and withanone ${ }^{1}$ compare to other variety of Ashwagandha found in India. One more important factor is pollution which affects the quality of the herbs. Safety is hampered by the heavy metal contamination and pesticides. 


\section{B. Processing}

Processing is the one of the important factor which affects the therapeutic value, saftey and toxicity of the drug as it is said that by using Sanskara (processing) efficacy of any medicine can be altered (increased or decreased) irrespective of its $\operatorname{dose}^{2}$. In ancient time science and the knowledge of our seers were highly developed. Medicines were being prepared by the physicians themselves from the process of picking the right herb to grinding, processing and pill making, all the activities were performed by the physician or under his keen observation. Those people were highly awared about the poisounous herbs, minerals and heavy metals. So many methods for the purification of heavy metals and poisonous herbs were being used that time. Traditional methods for the drug manufacturing were very tedious and time consuming. Today due to mechanization time and manpower has been reduced at the same time it has also interfered with the quality of the Ayurvedic medicines especially in the case of herbo-mineral formulations. There are so many ayurvedic formulations which contain poisonous herbs and minerals as an active ingredient which needs proper Shodhana (purification). These ingredients can produce harmful effects if not processed properly at the time of manufacutring.

\section{Storage}

Storage is also a big issue affecting the quality and safety of Ayurvedic medicines. Ayurveda suggest that therapeutic value and potential of different form of Aurvedic medicine like Choorna (Powder), Avleha (Medicinal jams) are different and the potential or the medicinal property of these drug suppose to decrease gradually according to the specific time $^{3}$. Choorna having salt as ingredient being hygroscopic may lose its quality or further may be contaminated by any fungus. Similarly different Avleha (medicinal jams) formulations which are having sugar or jaggery as one major ingredient, if not stored properly may develop fungus contamination.

\section{Adulteration issue}

Adulteration is a big factor related to the subject not only in India but also for the Chinese herbs. Most of the surveys conducted to carry out the market sample for some given herb, reveals aldultration and substitution in the market. There are so many herbs mentioned in classical texts of Ayurveda, which are ambiguous or not properly identified yet viz. Asthavarga of used in formation of a very well known Ayurvedic formulation Chyavanprash ${ }^{4}$. In place of Astavarga Dravya other substitute herbs are being used. Ashokarista ${ }^{5}$ being used as health tonic for female health contains Ashoka (Saraca Indica) as chief ingredient but it has been reported that various market preparations does not contains Ashoka, manufactures use its substitute Nakli Ashoka (Polyalthia longifolia) as Ashoka is marked as vulnerable species. Due to adultration and substitution of herbs can alter the efficcay of the drug. It may be decrease because of addition of inert substances or may be increased due to addition of pharmacologicaly active substances.

\section{E. Manufacturing}

Quality assurance and control measures, such as national quality specification and standards for herbal materials, good manufacturing practices (GMP) for herbal medicines, labeling, and licensing schemes for manufacturing, imports and marketing, should followed strictly. These measures are crucial for ensuring the safety and efficacy of herbal medicines. World Health Organization (W.H.O) also advises to follow the Good Agricultural and Good Collection practices (GACP) for medicinal plants that include plant selection and cultivation ${ }^{6}$. Unfortunately in India in regards to manufacturing of Ayuvedic drugs GMP is not followed by most of the manufactures.

\section{F. Drug packaging and prescribing leaflets}

Packaging leaflets or packing of Ayurveda medicine is completely different. Manufactures provide the information of the drug, dose, and the clinical use. But in many cases there is no clear cut indication regarding the clinical use of the drugs or sometimes contraindications are missed out. In some cases there are so many indications but the dose is not indicated for all those. All these defects create a question mark over the safety and the efficacy of the drug.

\section{G. Lack of pre marketing clinical trials}

Increased emphasis on lifestyle and wellness, driven by rise in non-communicable and chronic disease, is driving the demand for Ayurveda, as it is getting attraction of the society; the global market for Ayurveda is also growing. It is expected to almost treble from 3.4 billion dollar in 2015 to 9.7 billion dollars by $2022^{7}$. There are very few manufactures which deal with the classical Ayurvedic formulations and follow the standard methods for manufacturing the Ayuverdic products. So many small units are mushrooming and manufacturing Ayurvedic drugs and getting in to the market. Even the pharmaceutical companies dealing with allopathic medicines are manufacturing Ayurvedic drugs. Most of them are manufacturing proprietary products with just by combining the ingredients of different formulations indicated for particular disease as mentioned in the classical texts. Even the products are not clinically proved, without any pre marketing trials they are marketing the products by convincing the local practitioners.

\section{Factors in clinical use}

For a good clinical practice one should have a sound knowledge of different basic concept of Ayurveda Science viz. Dosha (three vital humours), Dushya (body tissues), Agni (digestive fire), Srotasa (Body chanelles), Kriyakala (stages of pathogenesis), Dravyaguna (Pharmacological 
properties) and Prakriti (the body-mind type). Apart from these one should also know about the different classical formulations viz. Choorna (Powders), Bhasma (Metalic Ashes), Rasaushadh (Herbo-mineral compounds containg mercury), Asava \& Arista (liquid formulations with self generated alcohols) etc, their ingredients, Pharmacological properties (Rasa, Guna, Veerya Vipaka) doses and indications. Lack of proper knowledge of Ayurveda may lead to poor clinical practice and also may create some adverse events to the patient. Prescribing medicine without knowing the pharmacological property of the medicine and the Prakriti (body-mind type) can be dangerous.

\section{A. Failure to adhere to the prescribing information}

In Ayurveda classics there are some limited indications for prohibited use of some medicines i.e Pippali (Piper longum), Kshar (Alkali ashes) and Lavana (Salt) ${ }^{8}$ but most of the places it is advised to the physician to use his own intellect and experience to decide the doses and duration of the drugs before prescribing. In current practice it has been observed that the dose in this regard is generally followed but the duration is ignored most of the times, thinking that it is safe as it is mentioned in the classics. Even the patient some times after getting benefitted by any medicines, continue to use those medicine without further consulting the physician. These types of practices should be strictly stopped as inapropiate and long term use of some Ayurvedic medicines can produce some harmful impact on health, drug induced liver injury due to prolonged consumtion of Kanchnar Gugglu and Punarnava Mandoor is revealed by a study?.

\section{B. Guidelines for drug administration in Ayurveda}

Ayurvedic pharmacology also include time of drug administration (Aushadasevanakaala), drug adjuvant (Anupaana) and diet/regimen restrictions (Pathya-Apathya sevana) for proper, effective and specific action on target site. Most importantly, it helps to overcome the untoward or toxic effects of the drug. Kulathha (horsegram) is contraindicated during the use of Shilajatu Rasyana ${ }^{10}$ and Yograj, a minerelo-herbal formulation used to treat anemia $^{11}$.

\section{Combination with modern medicine}

In the cases of life style related disorders most of the times it has been observed that Ayurvedic medicines are allowed to take with the allopathic medicines without knowing the impact of such combination. Inappropriate combination might be a possible reason for any adverse drug reaction. Interaction between herbal drugs and conventional medicines is gaining raising concern due to report of some potential interactions ${ }^{12}$ any coadministraion of herbs with modern or sysnthetic medicine can lead to antagonis or potentiation of the drug used ${ }^{13}$. Sometimes herbs or ayurvedic formulation can alter the phramecodynamics or phramacokintics of coventiontional medicine if used laong with. Shankphuspi a very well known Ayurvedic formutaion used as Medhya Rasayana (nervine tonic) has been rreported to reduce the anti epliptic property of phenytoin and its plasma concentration ${ }^{14}$.

\section{CURRENT STATUS}

In India, the initiatives for Pharmacovigilance for traditional medicines were initiated up in the form of workshops. In collaboration with WHO, clinical pharmacologist Urmilla Thatte and Vaidya Supriya Bhalerao organized a workshop, 'Pharmacovigilance of Ayurvedic Medicine' on 20 and 21 November, $2006^{15}$. In this direction next step was taken by department of Rasa shastra and Bhaisjya kalpna, IMS, BHU, who organized a seminar cum workshop titled as 'Safety Profile of Ayurvedic Dosage Forms' ${ }^{16}$. In the year 2007 after a successful workshop on the possibility of implementing pharmacovigilance programs for Ayurvedic medicine, Department of AYUSH, Ministry of Health and Family Welfare, Govt. of India, New Delhi, requested IPGTRA to prepare a protocol and ADR reporting format to implement pharmacovigilance for Ayurveda, Siddha, and then in year 2008-09, Institute for Post Graduate Teaching and Research in Ayurveda (IPGTRA), Gujarat Ayurved University, Jamnagar, was recognized as National Pharmacovigilance Resource Centre for Ayurveda, Siddha and Unani Drugs (NPRC-ASU) under the Central sector scheme for upgradation to Centre of Excellence

Unani (ASU) drugs ${ }^{17}$. After the establishment of Ministry of AYUSH in year 2014, many questions have been raised freuently from different sources regarding the quality and saftey assurence of Ayurvedic drugs. Keeping all these things in view, Ministry of AYUSH, introduced new Central Sector scheme for promoting pharmacovigilance of Ayurveda, Siddha, Unani and Homoeopathy (ASU\&H) Drugs. Prime objective of the scheme is to develop the culture of documenting adverse effects and undertake safety monitoring of Ayurveda, Siddha, Unani and Homoeopathy drugs and surveillance of misleading advertisements appearing in the print and electronic media. The Standing Finance Committee (SFC) chaired by Secretary (AYUSH) approved the scheme on 1st November, 2017 and thereafter it was rolled out for implementation in the country near the end of financial year 2017-18. The scheme intends to facilitate the establishment of three-tier network of National Pharmacovigilance Centre (NPvCC), Intermediary Pharmacovigilance Centres (IPvCCs) and Peripheral Pharmacovigilance Centres (PPvCC). All India Institute of Ayurveda, New Delhi, an autonomous body under the Ministry of AYUSH, has been designated as National Pharmacovigilance Centre for coordinating various activities of the initiative. In the initial phase of implementation, five National Institutes of AYUSH are designated as the Intermediary Pharmacovigilance Centres 


\section{International Journal of Engineering Applied Sciences and Technology, 2020 \\ Vol. 5, Issue 2, ISSN No. 2455-2143, Pages 251-254 \\ Published Online June 2020 in IJEAST (http://www.ijeast.com)}

and forty two institutions of AYUSH having clinical facilities as Peripheral Pharmacovigilance Centres to take up the work of reporting, documentation, analysis, causality assessment of the adverse reactions and events associated with the consumption of Ayurveda, Unani, Siddha and Homoeopathy drugs.

\section{CONCLUSION}

Pharmacovigilance practice is the need of time for all kind of traditional system of medicine including Indian system of medicine. Keeping the objectives of safety and efficacy it is really required and the current efforts should be accelerated. Education, training and publicity regarding pharamacovigilance of Ayush Drugs should be implemented at each and every required level. Regulatory and monitoring bodies should be developed and focus of AYUSH drugs safety surveillance should be prioritized.

\section{ACKNOLEDGEMENT}

The authors highly acknowledge the technical support provided by the Incharge R.A.R.I.D.D, Gwalior.

\section{REFERENCES}

1. A run Kumar et al (2007) Morphological and chemical variation in 25 collections of the Indian medicinal plant, Withania somnifera (L.) Dunal (Solanaceae), Genet Resour Crop Evol (54:655-660)

2. Shastri S.N. elaborated vidyotani hindi commentary on Charak Samhita Kapla Sthan chapter 12, verse 48, Chaukhambha Bharti Prakashan, Reprint edition, 2012 (p945)

3. Tripathi Brahmanand edited deepika Hindi commentary on sharangdhar samhita, Poorvakhanda, Chapter 1 verse 5557, Chaukhambha Sur Bharti Prakashan reprint edition 2010 (P-18)

4. Shastri S.N. elaborated vidyotani hindi commentary on Charak Samhita Chikitsa Sthan chapter 1, verse 63-69, Chaukhambha Bharti Prakashan, Reprint edition, 2012 (p56)
5. Mishra S.N., Edited Siddhiprada hindi commentary on Bhaisjya Ratnwali, Chapter 66, verse 111-114, , Chaukhambha Sur Bharti Prakashan, edition 2015

6. WHO guidelines on good agricultural and collection practices (GACP) for medicinal plants. Geneva, World Health Organization, 2003.

7. Report by Confederation of Indian Industry (CII) and PricewaterhouseCoopers (PwC).

8. Shastri S.N. elaborated vidyotani hindi commentary on Charak Samhita Viman Sthan, chapter 1, verse 15, Chaukhambha Bharti Prakashan, Reprint edition, 2012 (p677)

9. Kunal K Dalal et al (2017) World J Hepatol, 9(31): (1205-1209)

10. Shastri S.N. elaborated vidyotani hindi commentary on Charak Samhita Chikitsa Sthan chapter 1, verse 62, Chaukhambha Bharti Prakashan, Reprint edition, 2012 (p48)

11. Shastri S.N. elaborated vidyotani hindi commentary on Charak Samhita Chikitsa Sthan chapter 16, verse 84, Chaukhambha Bharti Prakashan, Reprint edition, 2012 (p500)

12. Izzo, A.A., Carlo, G.D., Borrelli, F., et al. (2005), Complementary pharmacotherapy and herbal medicines: the risk of drug interaction. Int. J. Cardiol., International Journal of (98:1-14.)

13. A.F. Berman (2000), Herb drug Interaction, Lancet 355, (p-134-138)

14. U.P. Dandekar, R.S. Chandra, S.S. Dalvi, M.V. Joshi and A.V Sharma, (1992), Analysis of a clinacally inportant interaction between phenytoin and Shankhpushpi, an Ayurvedic preparation, (35 285-288)

15.Thatte U. (2006) Proceedings of Pre conference workshop "Pharamacovigilance of Ayurvedic Medicines".

16. Chaudhary AK (Organising Secretary), (2007), Technical Report, WHO sponsored Seminar cum Workshop on Safety Profile of Ayurvedic Dosage Forms;

17. Galib M, Acharya R. (2008), National Pharmacovigilance Programme for Ayurveda, Siddha and Unani Drugs,AYU; $(29 ; 4 ; 1)$ 